\title{
UNITY OF THE FUNDAMENTAL AND APPLIED COMPONENTS OF THE CONTENT OF THE GENERAL PHYSICS COURSE AS A NECESSARY FOR THE FORMATION OF THE MAYBUZITAL PROFESSIONAL COMPETENCE
}

\section{ЄДНІСТЬ ФУНДАМЕНТАЛЬНОЇ ТА ПРИКЛАДНОЇ СКЛАДОВИХ ЗМІСТУ КУРСУ ЗАГАЛЬНОЇ ФІЗИКИ ЯК НЕОБХІДНА УМОВА ФОРМУВАННЯ ФАХОВОЇ КОМПЕТЕНТНОСТІ МАЙБУТНІХ УЧИТЕЛІВ ФІЗИКИ}

\author{
Sergey VASYLENKO, \\ Candidate of Physical and \\ Mathematical Sciences, Associate \\ Professor \\ Сергій ВАСИЛЕНКО, \\ кандидат фрізико-математичних \\ наук, доцент \\ kzf@ukr.net \\ National Pedagogical \\ Національний педагогічний \\ університет \\ M.P. Drahomanov University \\ $\triangle 9$ Pirogova St., \\ Kyiv, 01601 \\ імені М.П. Драгоманова \\ вул. Пирогова, 9, м. Київ, 01601 \\ Original manuscript received: October 06, 2019 \\ Revised manuscript accepted: December 16, 2019
}

\begin{abstract}
The article emphasizes the need to combine the fundamental and applied components of the content of the General Physics course in the training of future physics teachers. It is emphasized that the modern stage of scientific and technical development of society places high demands on the intellectual potential of future teachers of physics, to possess their methodology of scientific research. It is established that the content of the discipline "General Physics" should reflect the current state of development and achievements of science, and students should have the latest methods of research, orientation skills in the flow of scientific information and use it to perform the tasks of professional activity. It is noted that in this context special attention deserves such field of physics as nanophysics. It is shown that a deeper acquaintance of students with the questions of nanophysics opens opportunities for modern interpretation of the material learned in the previous stages of study, to understand its real applied value in relation to the possibilities of their use in practice. The problems that arise during the formation of knowledge in the field of modern achievements in nanophysics in the future teachers of physics, among which the main problem is to ensure the unity of the fundamental and applied components of the content of the course of general physics. It is emphasized that scientific and methodological literature should be developed in order to popularize knowledge about the current state of nanotechnology development and research into the properties of nano-objects.
\end{abstract}


Серія: Педагогічні науки. - Вип.3. - Бердянськ : БДПУ, 2019. - 453 с.

Methodical approaches to acquaint future physics teachers with modern achievements of nanotechnologies and their use in various fields of science and technology are proposed. It is shown that the integration of nanotechnology into the general physics course helps students to understand the applied aspects of modern science and provides a scientific outlook, which contributes to the formation of a high level of professional competence of the future physics teacher.

Key words: fundamental and applied components of the content of general physics course, future teachers of physics, nanophysics, nanotechnology.

Сучасний етап науково-технічного розвитку суспільства висуває нові, набагато вищі вимоги до творчого потенціалу фахівців, що передбачає володіння науковими методами, вміння орієнтуватися в потоці наукової інформації, знаходити найраціональніші конструкторські, технологічні й організаційні рішення. Перед представниками різних наукових напрямків дедалі частіше постають завдання, які вимагають, окрім суто фахової компетентності, знань щодо методів опрацювання результатів спостережень, планування експериментів, моделювання та оптимізації проблем дослідження. Отже, сучасний фахівець повинен мати не лише глибоку професійну підготовку, а й певний обсяг знань у галузі наукових досліджень, що передбачає засвоєння методологічних засад наукової праці. Що ж стосується вчителів фрізики, то для них ці вимоги є вкрай актуальними, оскільки фрізика як наука про явища природи становить фундамент усього сучасного природознавства, їй належить виняткове місце в загальній системі знань, накопичених людством. Тому в закладах вищої педагогічної освіти вивченню фрізики має приділятися особлива увага, оскільки для майбутніх вчителів вона надалі стане професією. Зважаючи на це, зміст дисципліни “Загальна фрізика" повинен відображати сучасний стан розвитку і досягнень науки, а студенти мають оволодівати новітніми методами досліджень, вміннями орієнтуватися в потоці наукової інформації та використовувати її для виконання завдань професійної діяльності.

Очевидно, що посиленню пізнавального інтересу майбутніх учителів до питань, які відображають сучасний стан розвитку фрізики, сприяють новизна і перспективність навчальної інформації. У цьому контексті на особливу увагу заслуговує така галузь фізики, як нанофізика, зокрема, особливості квантових ефектів у нанокомпозитах, інноваційні принципи створення матеріалів та нанорозмірних структур з необхідними функціональними властивостями. Більш глибоке ознайомлення студентів з питаннями нанофізики та нанокомпозитів відкриває можливості для усвідомлення матеріалу, засвоєного на попередніх етапах навчання, під новим кутом зору. Так, знайомі 3 курсу квантової фрізики модельні уявлення набувають для студентів реального прикладного значення у зв'язку із можливостями їх використання на практиці.

Проте під час формування в майбутніх вчителів фізики знань у галузі сучасних досягнень з нанофрізики мають місце суттєві проблеми, а саме: не забезпечується притаманна фізиці єдність фундаментальної і прикладної складових змісту; має місце академічність у навчанні відсутність належного взаємозв'язку опанованих знань з їх практичним 
застосуванням; виникають суперечності між необхідністю поглиблення фундаментальної підготовки студентів щодо питань, пов'язаних із поточним станом розвитку нанонауки і нанотехнологій, та значним відставанням освітніх програм для закладів вищої педагогічної освіти від сучасного стану розвитку фрізики як науки; немає узгодженості між потребою суспільства в розвиткові нанотехнологічної компоненти системи освіти на всіх рівнях та станом розробленості методики викладання нанонауки в закладах вищої та середньої освіти; відсутні науково-методичні джерела для популяризації знань про сучасний стан розвитку нанотехнологій та досліджень властивостей нанооб'єктів.

Використання методів теоретичного та емпіричного дослідження, зокрема, аналізу з метою виокремлення нерозв'язаних проблем та визначення шляхів їх розв'язання, синтезу для здійснення найбільш доцільного вдосконалення навчальної програми з дисципліни "Загальна фрізика", спостереження 3 метою визначення закономірностей навчального процесу, спрямованого на забезпечення єдності фундаментальної і прикладної складових змісту курсу фрізики, дозволили нам встановити, що нині $\epsilon$ необхідність комплексного виправлення ситуації, що склалася в підготовці з фрізики майбутніх вчителів фізики. Тому метою статті $\epsilon$ висвітлення методичних підходів до забезпечення єдності фундаментальної та прикладної складових змісту навчання фізики у підготовці майбутніх вчителів фрізики.

Окремі підходи до розв'язання зазначеної педагогічної проблеми розглянуті в теорії та методиці навчання фрізики в педагогічних університетах. Цим питанням присвячені наукові праці таких українських науковців, як Л. Благодаренко, О. Ляшенко, М. Мартинюк, В. Сергієнко, Н. Сосницька, М. Шут та інших. Проте наявні методичні розробки вимагають суттєвої модернізації відповідно до сучасного стану розвитку фізики.

Працюючи над оновленням змісту викладання загальної фізики, кафедра загальної та прикладної фрізики фрізико-математичного факультету Національного педагогічного університету імені М. П. Драгоманова ввела до навчального плану курс "Нанофрізика" та забезпечила створення відповідних навчально-методичних посібників для студентів, що відображають прикладні аспекти питань нанотехнологій.

Конкретизуємо окремі методичні підходи до забезпечення єдності фундаментальної та прикладної складових змісту курсу загальної фізики. Так, розглядаючи питання про традиційні та альтернативні джерела енергії, студентам слід повідомити, що наноматеріали в сонячних батареях забезпечують нові перспективи альтернативної енергетики. Важливо додати, що перспективність цих матеріалів полягає, насамперед, у тому, що вони (в комплексі з іншими джерелами енергії) здатні забезпечити енергетичні потреби людства зі збереженням екологічної рівноваги, в гармонії з навколишнім середовищем.

Під час ознайомлення студентів 3 основами молекулярнокінетичної теорії важливо акцентувати на досягненнях фармацевтичної промисловості, що створює лікарські препарати різних поколінь, які 
впливають на організм на молекулярному або нанорівні. Широка перспектива відкривається в галузі медичної техніки (розроблення засобів діагностики, виконання нетравматичних операцій, створення штучних органів), розробляються високоефективні засоби доставки ліків, виготовлених з використанням нанопрепаратів, до місць виникнення захворювання. Студентам буде корисно дізнатися, що сучасна медицина активно використовує унікальні властивості наноматеріалів і нанооб'єктів для відстеження, конструювання та зміни біологічних систем людини на наномолекулярному рівні. Крім того, останнім часом виник і бурхливо розвивається такий напрямок, як ДНК-нанотехнології використання специфічних властивостей молекул ДНК і нуклеїнових кислот для створення на їх основі чітко заданих структур. Молекулярна електроніка досліджує електронні наносистеми, що містять поодинокі молекули або молекулярні комплекси, а також технології виготовлення таких наносистем, які засновані на використанні процесів самозбірки, включаючи процеси маніпулювання як поодинокими молекулами, так i молекулярними комплексами.

Під час ознайомлення студентів з принципами радіолокації слід наголосити, що шляхом використання малошумних НВЧ-транзисторів на основі наноструктур і волоконно-оптичних ліній зв'язку з підвищеною пропускною спроможністю можливості радіолокаційних систем значно розширюються. Вивчаючи питання, пов'язані 3 інтерференцією та дифракцією світла, студенти найбільш ефективно засвоюють навчальний матеріал, якщо супроводжувати його викладення інформацією про такі прикладні аспекти досліджуваних явищ, як просвітлення оптики, отримання 3D зображень тощо. Студентам також важливо знати фрізичні принципи, що лежать в основі оптоволоконних технологій, без яких неможливо уявити сучасну якісну передачу великих обсягів інформації. При вивченні геометричної оптики слід приділити увагу нанолінзам, які виробляються для військових і цивільних потреб та телевізійних екранів, створених на основі лінз Френеля. Важливо зупинитися на можливостях нанооптики, яка досліджує оптичні наносистеми, що виконують функції інформаційного управління, здійснюючи обробку, зберігання і передачу інформації у вигляді оптичних сигналів. Перспективним розділом нанооптики $€$ нанофотоніка, її елементну базу складають фотонні кристали, які ефективно використовуються в пристроях обробки, зберігання і передачі інформації.

Значні можливості для ознайомлення студентів з досягненнями нанотехнологій забезпечуються змістом навчального матеріалу атомної і ядерної фізики. Зокрема, при вивченні рівняння Шредінгера та розв'язанні на його основі найпростіших задач квантової механіки, коли студенти одержують початкові відомості про апарат квантової механіки, їм необхідно повідомити, що ці математичні методи широко використовуються у квантовій хімії, квантовій електроніці, при обробці даних рентгеноструктурного аналізу у кристалографії, важливість якої в сучасному приладобудуванні, орієнтованому на використання нанооб'єктів, важко переоцінити. Студентам необхідно повідомити, що 
цілеспрямоване розроблення нанотехнологій і створення наноматеріалів в атомній галузі було розпочате в середині минулого століття, практично одночасно з початком використання ядерної зброї. Слід акцентувати на тому факті, що нині активно розробляються функціональні речовини і вироби з використанням нанотехнологій i наноматеріалів для ядерної, термоядерної, водневої енергетики. Це дозволить знизити споживання природного урану при виробництві енергії. Важливо, що активація процесу згоряння за рахунок нанодобавок може виявитися одним з напрямків створення технологій нових видів уран-плутонієвих оксидів та нітридів для ядерного палива. При вивченні фізичних основ роботи лазерів студентам буде корисно дізнатися, що цікавим використанням лазерів $є$ лазерний пінцет, який ефективно використовується в нанотехнологіях. Також нині з'явилась можливість створення потужних інжекційних лазерів на основі використання наноструктур для здійснення процесу їх накачки.

Основна задача викладача фрізики полягає в тому, щоб студенти усвідомили: використання можливостей нанотехнологій у найближчій перспективі сприятиме збільшенню обсягу виробництва внутрішнього валового продукту та істотному економічному ефекту в таких базових галузях економіки, як машинобудування (за рахунок широкого впровадження нанотехнологій під час модернізації парку високоточних і прецизійних верстатів); автомобільна промисловість (за рахунок використання нових наноматеріалів та більш точної обробки поверхні деталей досягається значне (у 1,5-4 рази) збільшення ресурсу роботи автотранспорту, а також зниження експлуатаційних витрат (у тому числі витрат палива); електроніка та оптоелектроніка (за рахунок освоєння нових частотних діапазонів під час створення засобів зв'язку з використанням наноелектронних систем). Важливо наголосити, що нині створюються нові наноматеріали для багатофункціонального застосування в оптоелектроніці та нелінійній оптиці, розвивається інформатизація за рахунок багаторазового збільшення обсягу пам'яті та продуктивності системи обробки, зберігання і передачі інформації, а також відбувається розроблення нових високоефективних швидкісних пристроїв 3 наближенням можливостей обчислювальних систем до властивостей, притаманних об'єктам живої природи з елементами інтелекту.

Під час дослідження фізичних основ сучасних екологічних проблем студентам необхідно розповісти, що нині в нанотехнологіях започатковано новий напрям - нанобезпека та захист від можливого негативного впливу нанооб'єктів (дослідження потенційних ризиків для людини під час взаємодії з наночастинками). В охороні навколишнього природного середовища за рахунок використання фрільтрів і мембран, виготовлених на основі наноматеріалів, а також новітніх нанодатчиків здійснюватиметься очищення води і повітря, опріснення морської води, охорона навколишнього природного середовища під час зберігання та переробки відпрацьованого ядерного палива та моніторинг всіх технологічних процедур керування якістю монтажу та експлуатації ядерних систем. Зокрема, у зв'язку із потребами радіаційної безпеки 
Серія: Педагогічні науки. - Вип.3. - Бердянськ : БДПУ, 2019. - 453 с.

виник новий напрям матеріалознавства - створення об'ємних сцинтиляційних матеріалів на нанорозмірних люмінофорах.

Досвід показує, що включення питань нанотехнологій до курсу загальної фрізики допомагає в більш поглибленому розумінні студентами прикладних аспектів сучасної науки та забезпечує становлення наукового світогляду, що сприяє фрормуванню високого рівня фрахової компетентності майбутнього вчителя фрізики. Наукова інформація, яка висвітлює конкретні аспекти сучасної фрізики, зокрема, нанотехнологій, дозволяє вирішити низку важливих завдань, а саме: для студентів популярне нині слово "нанотехнологіі" наповнюється конкретним змістом, таким чином формується технічна культура у використанні термінології; конкретні моделі, які $\epsilon$ фундаментальними в курсі загальної фрізики та ілюструють фізичний зміст фізичних явищ, набувають підвищеної значимості, оскільки демонструють зв'язок знань, отриманих при вивченні фрізики, з вимогами сьогодення. Таким чином, доцільним є включення понять сучасної науки та нанотехнологій до загального переліку фундаментальних фрізичних термінів і уявлень. Зрозуміло, що методичні підходи до ознайомлення майбутніх учителів фрізики із сучасними можливостями нанотехнологій є особливо ефективними, якщо вони реалізуються на базі сучасних інформаційно-комунікаційних технологій. Використання відповідного інформаційного середовища вносить у навчальний процес нові можливості, поєднуючи його високу педагогічну ефективність та гнучкість, суттєве розширення можливостей традиційних форм навчання, а також створення інноваційних моделей освітнього процесу.

Отже, у процесі засвоєння основ нанофізики студенти мають усвідомити, що створення теорій у цій галузі ґрунтується на величезному експериментальному матеріалі, який здобувається працею вчених; нанофізика $€$ основою сучасної нанотехніки і нанотехнологій (нанотранзистори, нанолазери, наноелектроніка тощо); методи дослідження нанокомпозитів широко використовуються в хімії, біології, геології та інших галузях науки. Подальші напрацювання в цьому напрямку слід спрямувати на розроблення методичних підходів до підвищення рівня обізнаності майбутніх вчителів фізики в галузі сучасних досліджень наноматеріалів (нанокомпозитів), що в значній мірі сприятиме забезпеченню єдності фундаментальної та прикладної складових змісту дисципліни “Загальна фізика”.

\section{Література}

1. Шут M.І. Фізична освіта в педагогічних університетах: стан і перспективи / M.І. Шут, Л.Ю. Благодаренко // Дидактичні механізми дієвого формування компетентнісних якостей майбутніх фрахівців фрізико-технологічних спеціальностей: збірник матеріалів XI міжнародної наукової конференції / [редкол.: П.С. Атаманчук (голов. ред..) та ін.]. Кам'янець-Подільський: ТОВ “Друкарня Рута”, 2016. - С. 42 - 44.

2.Шут М.І. Значення змісту навчання фрізики для реалізації завдання підготовки компетентного вчителя / М.І. Шут, Л.Ю. Благодаренко // Матеріали науково-практичної конференції [“Засоби і технології сучасного навчального середовища"], (Кіровоград 19-20 травня 2017 р.) / Відповідальний редактор: С.П. Величко. - Кіровоград : ПП “Ексклюзив-Систем”, 2017. - С.43-46.

3.Шут М.І., Благодаренко Л.Ю. Якісна вища освіта - основа державності України / М.І. Шут, Л.Ю. Благодаренко //Матеріали Всеукраїнської науково- 
практичної конференції з міжнародною участю “Фундаментальна підготовка фахівців у природничо-математичній, технічній, агротехнологічній та економічній галузях" [авт. кол.: Благодаренко Л.Ю., Кюрчев В.М., Сосницька Н.Л., Шут М.І. та ін.]. - Мелітополь: ТОВ “Колор Принт”, 2017. - С. 185-187.

\section{References}

1.Shut M.I. Fizychna osvita v pedahohichnykh universytetakh: stan i perspektyvy / M.I. Shut, L.lu. Blahodarenko // Dydaktychni mekhanizmy diievoho formuvannia kompetentnisnykh yakostei maibutnikh fakhivtsiv fizyko-tekhnolohichnykh spetsialnostei: zbirnyk materialiv Khl mizhnarodnoi naukovoi konferentsii / [redkol.: P.S. Atamanchuk (holov. red..) ta in.]. - Kamianets-Podilskyi: TOV “Drukarnia Ruta”, 2016. - S. 42 - 44.

2.Shut M.I. Znachennia zmistu navchannia fizyky dlia realizatsii zavdannia pidhotovky kompetentnoho vchytelia / M.I. Shut, L.lu. Blahodarenko // Materialy naukovo-praktychnoi konferentsii ["Zasoby i tekhnolohii suchasnoho navchalnoho seredovyshcha"], (Kirovohrad 19-20 travnia 2017 r.) / Vidpovidalnyi redaktor: S.P. Velychko. - Kirovohrad : PP "Ekskliuzyv-System", 2017. - S.43-46.

3.Shut M.I., Blahodarenko L.lu. Yakisna vyshcha osvita - osnova derzhavnosti Ukrainy / M.I. Shut, L.lu. Blahodarenko //Materialy Vseukrainskoi naukovo-praktychnoi konferentsii z mizhnarodnoiu uchastiu "Fundamentalna pidhotovka fakhivtsiv u pryrodnycho-matematychnii, tekhnichnii, ahrotekhnolohichnii ta ekonomichnii haluziakh" [avt. kol.: Blahodarenko L.lu., Kiurchev V.M., Sosnytska N.L., Shut M.I. ta in.]. Melitopol: TOV "Kolor Prynt", 2017. - S. 185-187.

\section{АНОТАЦІЯ}

У статті наголошується на необхідності поєднання ффундаментальної $i$ прикладної складових змісту курсу загальної фрізики в підготовці майбутніх вчителів фізики. Наголошено, що сучасний етап науково-технічного розвитку суспільства висуває високі вимоги до інтелектуального потенціалу майбутніх вчителів фрізики, володіння ними методологією наукових досліджень. Встановлено, що зміст дисципліни "Загальна фрізика" повинен відображати сучасний стан розвитку i досягнень науки, а студенти мають володіти новітніми методами досліджень, вміннями орієнтації в потоці наукової інформації та використання ії для виконання завдань професійної діяльності. Відзначено, що в цьому контексті на особливу увагу заслуговує така галузь фрізики, як нанофрізика. Показано, що більш глибоке ознайомлення студентів з питаннями нанофізики відкриває можливості для сучасної інтерпретації матеріалу, засвоєного на попередніх етапах навчання, для розуміння його реального прикладного значення у зв'язку із можливостями їх використання на практиці. Виокремлено проблеми, які мають місце під час фоормування в майбутніх вчителів фрізики знань у галузі сучасних досягнень з нанофізики, серед яких основною $\epsilon$ проблема забезпечення єдності фундаментальної і прикладної складових змісту курсу загальної фрізики. Наголошено на необхідності розроблення науковометодичної літератури для популяризації знань щодо сучасного стану розвитку нанотехнологій та досліджень властивостей нанооб'єктів. Запропоновано методичні підходи до ознайомлення майбутніх вчителів фрізики з сучасними досягненнями нанотехнологій та їх використанням в різних галузях науки і техніки. Показано, що включення питань нанотехнологій до курсу загальної фрізики допомагає в більш поглибленому розумінні студентами прикладних аспектів сучасної науки та забезпечує становлення наукового світогляду, що сприяє формуванню високого рівня фрахової компетентності майбутнього вчителя фрізики.

Ключові слова: фрундаментальна і прикладна складові змісту курсу загальної фрізики, майбутні вчителі фрізики, нанофрізика, нанотехнології. 